\title{
Medico-legal documentation of rape or sexual assault: are community-service doctors equipped for the task?
}

\author{
L Fouchéa, J Bezuidenhout ${ }^{\mathrm{a}}$, C Liebenberg ${ }^{\mathrm{b}}$ and AO Adefuye ${ }^{\mathrm{a} *}$ (D) \\ ${ }^{a}$ Division of Health Sciences Education, Office of the Dean, University of the Free State, Bloemfontein, South Africa \\ ${ }^{b}$ Department of Forensic Medicine, School of Medicine, University of the Free State, Bloemfontein, South Africa \\ ${ }^{*}$ Corresponding author, email: AdefuyeAO@ufs.ac.za
}

Background: Following upon two-year internship, community-service doctors make mistakes when they deal with evidence of medico-legal examinations in various settings. These mistakes result in alleged perpetrators being released by courts. This study investigated undergraduate clinical forensic medicine training, based on experiences and opinions of community-service doctors. This article focuses on incidents of alleged rape cases only.

Methods: The study was a quantitative retrospective cohort study that made use of a questionnaire with an adapted Likert scale. An electronic survey tool was employed to target 150 community-service doctors throughout South Africa. Percentages are used to display results.

Results: A response rate of $59.3 \%$ was achieved. Although $80 \%$ of the participants reported that they had undergraduate training on how to manage alleged rape or sexual assault cases, only $11.4 \%$ of the participants had hands-on exposure to an alleged rape case during their undergraduate training. In addition, the majority of the participants $(77.1 \%)$ never had undergraduate training on how to complete the $\mathbf{J} 88$ form. These findings indicate that clinical forensic training in the undergraduate medical programme does not adequately prepare community-service doctors to meet the challenges of clinical forensic practice. The current curriculum should be adapted to address these shortcomings.

Conclusions: Perpetrators cannot be convicted if evidence collected cannot stand up in court. Proper training of undergraduate medical students prior to their community-service posting will ensure that medico-legal documentation is completed correctly, leading to the presentation of credible evidence in a court of law in order to ensure successful conviction of alleged perpetrators.

Keywords: clinical forensic medicine, community-service doctors, medical training, medico-legal documentation, sexual assault

\section{Introduction}

Sexual assault and rape are violent crimes and among the most demoralising of personal traumas, often leaving victims physically assaulted, emotionally traumatised or even dead. ${ }^{1}$ According to the (Sexual offences And Related Matters) Amendment Act 32 of 2007 of the Republic of South Africa, any person ('A'), who unlawfully and intentionally commits an act of sexual penetration with a complainant ('B') without the consent of $B$, is guilty of the offence of rape. ${ }^{2}$ This Act makes provision that both men and women can be raped..$^{2}$

South Africa has one of the highest incidences of rape in the world. ${ }^{1}$ However, statistics on rape of men in South Africa are not available, as most male rapes go unreported. ${ }^{3}$ According to the South African Police Service (SAPS) 2015/2016 annual crime report, 41503 incidents of rape were reported between 1 April 2015 and the 31 March 2016-approximately 114 rape incidents per day. ${ }^{4}$ The SAPS states that the number of rape cases decreased by $3.9 \%$ from the preceding year, following a year-on-year decrease since 2012/2013. ${ }^{4}$ The question arises as to whether the figures released by the SAPS reflect an actual reduction in the number of rapes reported, or a reduction in the incidence of rape. $^{5}$ The National Institute for Crime Prevention and Rehabilitation (NICRO) states that only one in 20 incidents of rape is reported to the SAPS and that the SAPS figures do not reflect the reality of what is happening in the community. It is acknowledged that lack of faith in the criminal justice system and medical services are among the major barriers to reporting and successfully prosecuting sexual offenders. ${ }^{5,6}$
The objective of this study was to assess the knowledge and experience of community-service doctors in medico-legal documentation and management of adults/adolescent patients who reported being raped, with the aim of highlighting the shortfalls of the present curriculum for clinical forensic medicine training in the undergraduate $\mathrm{MBChB}$ programme in South Africa.

\section{Methods}

This study was a quantitative retrospective cohort study that used a questionnaire to obtain information concerning the knowledge, experiences and opinions of a cohort of communityservice doctors regarding clinical forensic medicine practice. The questionnaire was self-administered, and was administered once. The study cohort comprised MBChB graduates who had just completed their community service or were still in service during the period of survey.

The contact details of the potential participants were sourced from the Health Professions Council of South Africa. All potential participants were contacted telephonically to obtain verbal consent.

A total of 150 questionnaires were dispatched electronically via email. Data collected include the following:

- Demographics: age, gender and home language;

- Professional profile: information on when the participant had started and completed his/her medical studies.

- Employment profile: information on when and where participants had done/were doing community service; and 
- Experience of managing sexual assault/rape victims during the community-service year.

This study was approved by the Health Sciences Research Ethics Committee (HSREC 149/2011) of the Faculty of Health Sciences at the University of the Free State.

\section{Results}

A response rate of $59.3 \%$ was obtained by this study: 89 of the 150 questionnaires distributed were returned. Some participants did not answer all the questions.

\section{Demographic and professional details of participants}

Data regarding age, gender, language, academic history, completion of studies, and information as to when and where the participants were doing/had done their community service were obtained.

\section{Age and gender distribution}

The average age of the majority of participants (40.9\%) was 28 years. Of the 89 doctors who participated in this study, $61.8 \%$ were women and $38.2 \%$ men.

\section{Home language}

In response to this survey, $73 \%$ of participants reported Afrikaans as their home language, $15.7 \%$ reported English as being their home language and $11.2 \%$ had another language as home language $(n=89)$.

\section{Community service location}

Regarding the province of service, $39.3 \%$ of participants were posted to communities in the Free State while $13.5 \%$ and $12.4 \%$ of participants did their community service in the North West and Northern Cape, respectively (Figure 1). Furthermore, 47.2\% of participants did their community service in urban settings, whilst $27.9 \%$ of participants did their community service in a mixed urban and rural setting. About a quarter of participants $(25.8 \%)$ did their community service in rural settings.

\section{Alleged rape incidents encountered during year of community service}

As shown in Table 1, only 39.3\% $(n=35)$ of the participants encountered incidents of rape or sexual assault during their year of community service. The frequencies on the questionnaire

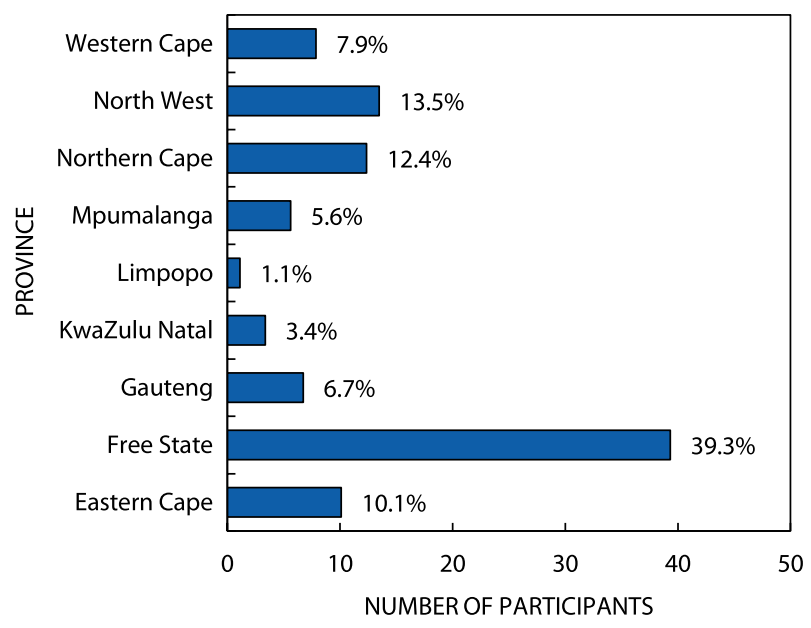

Figure 1: Province of community service $(n=89)$.
Table 1: Number of rape cases encountered by participants during community-service year

\begin{tabular}{|c|c|c|c|c|}
\hline Factor & & Yes \% (n) & No \% (n) & \\
\hline $\begin{array}{l}\text { Encountered } \\
\text { incidents of } \\
\text { rape }(n=89)\end{array}$ & & $39.3(35)$ & $60.7(54)$ & \\
\hline \multirow{2}{*}{$\begin{array}{l}\text { Number of } \\
\text { rape cases } \\
\text { examined } \\
(n=35)\end{array}$} & $1-5$ cases & $5-10$ cases & $10-20$ cases & $\begin{array}{c}20 \text { or more } \\
\text { cases }\end{array}$ \\
\hline & 37.1 (13) & $17.1(6)$ & $20.1(7)$ & $25.7(9)$ \\
\hline
\end{tabular}

Table 2: Recording detailed histories of patients who alleged being raped $(n=35)$

\begin{tabular}{lccc}
\hline History recorded & $\begin{array}{c}\text { Yes, always } \\
\%(n)\end{array}$ & $\begin{array}{c}\text { Yes, sometimes } \\
\%(n)\end{array}$ & $\begin{array}{c}\text { No } \\
\%(n)\end{array}$ \\
\hline $\begin{array}{l}\text { Details of the } \\
\text { alleged rape or } \\
\text { sexual assault }\end{array}$ & $82.9(29)$ & $17.1(6)$ & $0(0)$ \\
$\begin{array}{l}\text { Details of the } \\
\text { gynaecological } \\
\text { history }\end{array}$ & $77.1(27)$ & $20(7)$ & $2.9(1)$ \\
$\begin{array}{l}\text { Details of patient's } \\
\text { sexual history }\end{array}$ & $80(28)$ & $14.3(5)$ & $5.7(2)$ \\
\hline \begin{tabular}{l} 
Used an interpreter \\
\hline
\end{tabular} & $14.3(5)$ & $65.7(23)$ & $20(7)$ \\
\hline
\end{tabular}

were $1-5$ cases $(37.1 \%, n=13), 5-10$ cases $(17.1 \%, n=6), 10-20$ cases $(20.1 \%, n=7)$ and 20 cases or more $(25.7 \%, n=9)$.

\section{History-taking}

Analysis of data obtained by this study shows that only $82.9 \%$ ( $n=29$ ) of the participants who had encounters with rape or sexual assault case/cases during their community service year recorded detailed histories (Yes, always) of the alleged rape or sexual assault, while $17.1 \%(n=6)$ occasionally (Yes, sometimes) did so (Table 2). Furthermore, when asked whether they recorded detailed gynaecological and sexual histories of the patients, $77.1 \%(n=27)$ and $80 \%(n=28)$ of the participants reported that they always did. In a multicultural society, such as that of South Africa, where 11 languages are recognised as official languages, it is important for an interpreter to be present when obtaining a history from a patient who reports being raped. An interpreter could aid in ensuring that the correct information regarding the incident is obtained where there is a language difference between the doctor and the patient. The majority of the participants $(65.7 \%, n=23)$ reported occasionally using an interpreter (Table 2), suggesting that the participants and patients understood each other and did not need an interpreter in the other cases.

\section{Examination}

During the examination of a patient who reports having been raped, it is obligatory for a chaperone to be present, to ensure a safe environment for both the patient and the examining medical practitioner. Analysis of data from this study revealed that only $40 \%(n=14)$ of the participants always requested a chaperone to be present during an examination, while $22.9 \%$ $(n=8)$ examined the patient without a chaperone being present (Table 3).

Of the 34 participants who responded to the question relating to obtaining a patient's consent prior to examination, the majority 
Table 3: Procedures for examination of patients who alleged being raped $(n=35)$

\begin{tabular}{|c|c|c|c|}
\hline Procedures & $\begin{array}{c}\text { Yes, always } \\
\%(n)\end{array}$ & $\begin{array}{c}\text { Yes, sometimes } \\
\%(n)\end{array}$ & $\begin{array}{c}\text { No } \\
\%(n)\end{array}$ \\
\hline $\begin{array}{l}\text { Chaperone was } \\
\text { present }\end{array}$ & $40(14)$ & $37.1(13)$ & $22.9(8)$ \\
\hline $\begin{array}{l}\text { Obtaining consent } \\
\text { for examination** }\end{array}$ & $73.5(25)$ & $26.5(9)$ & $0(0)$ \\
\hline $\begin{array}{l}\text { Completing a gen- } \\
\text { eral examination }\end{array}$ & $68.8(24)$ & $25.7(9)$ & $5.7(2)$ \\
\hline $\begin{array}{l}\text { Noting the devel- } \\
\text { opmental stage } \\
\text { of the patient's } \\
\text { breasts }\end{array}$ & $60(21)$ & $22.9(8)$ & $17.1(6)$ \\
\hline $\begin{array}{l}\text { Noting the devel- } \\
\text { opmental stage } \\
\text { of the patient's } \\
\text { genitalia }\end{array}$ & $62.9(22)$ & $22.9(8)$ & $14.3(5)$ \\
\hline $\begin{array}{l}\text { Noting the } \\
\text { appearance of the } \\
\text { patient's anus }\end{array}$ & $74.3(26)$ & $22.9(8)$ & $2.9(1)$ \\
\hline $\begin{array}{l}\text { Noting injuries } \\
\text { on the patient's } \\
\text { genitalia }\end{array}$ & $88.6(31)$ & $8.6(3)$ & $2.9(1)$ \\
\hline $\begin{array}{l}\text { Familiar with J88 } \\
\text { form }\end{array}$ & $77.1(27)$ & * & $22.9(8)$ \\
\hline $\begin{array}{l}\text { Documented inju- } \\
\text { ries on the J88 }\end{array}$ & $97.1(34)$ & * & $2.9(1)$ \\
\hline $\begin{array}{l}\text { Placed original } \\
\text { J88 in kit before } \\
\text { sealing } \dagger\end{array}$ & $90.9(30)$ & * & $9.1(3)$ \\
\hline $\begin{array}{l}\text { Handed the sealed } \\
\text { kit to the investi- } \\
\text { gating officer }\end{array}$ & $68.6(24)$ & $25.7(9)$ & $5.7(2)$ \\
\hline $\begin{array}{l}\text { Experienced } \\
\text { difficulties with } \\
\text { the questions in } \\
\text { the J88 }\end{array}$ & 54.3 (19) & * & $45.7(16)$ \\
\hline
\end{tabular}

*Indicates that the option was not available for that particular question. ${ }^{* *} n=34$.

${ }^{+} n=33$.

(73.5\%, $n=25$ ) reported always obtaining consent prior to conducting the examination. When a patient reports being raped, detailed examination of the female genital and external anal region is essential. Of the 35 participants who reported treating patients who said they had been raped, $88.6 \%(n=31)$ always documented injuries on the genitalia (Table 3 ).

The $\mathrm{J} 88$ is a comprehensive form that has to be completed in duplicate by the practitioner who examines a patient reporting rape or sexual assault. Analysis of the data collected by this study shows that the majority $(77.1 \%, n=27)$ of participants who treated patients reporting being raped had prior knowledge of the J88 form, while $22.9 \%(n=8)$ had not. Similarly, $97.1 \%(n=34)$ of the participants documented examination findings on the J88 form (Table 3), suggesting that the other seven participants who came in contact with the J88 form for the first time while attending to a patient might have difficulty in completing the form or might have completed the form incorrectly. However, $54.3 \%(n=19)$ reported difficulties in completing the J88 form (Table 3).
Table 4: Adhering to procedures for collecting and handling forensic evidence $(n=35)$

\begin{tabular}{|c|c|c|c|}
\hline $\begin{array}{l}\text { Forensic } \\
\text { samples } \\
\text { collected }\end{array}$ & $\begin{array}{c}\text { Yes, always } \\
\%(n)\end{array}$ & $\begin{array}{c}\text { Yes, sometimes } \\
\%(n)\end{array}$ & $\begin{array}{l}\text { No } \\
\%(n)\end{array}$ \\
\hline $\begin{array}{l}\text { Familiar with } \\
\text { SAECK prior to } \\
\text { community service }\end{array}$ & $68.6(24)$ & * & $31.4(11)$ \\
\hline $\begin{array}{l}\text { Collected relevant } \\
\text { samples for foren- } \\
\text { sic evidence }\end{array}$ & $85.7(30)$ & $11.4(4)$ & $2.9(1)$ \\
\hline $\begin{array}{l}\text { Swabbed bite } \\
\text { wounds }\end{array}$ & $70.6(25)$ & $2.9(1)$ & $26.5(9)$ \\
\hline $\begin{array}{l}\text { Swabbed under } \\
\text { the fingernails }\end{array}$ & $51.4(18)$ & $37.1(13)$ & $11.4(4)$ \\
\hline $\begin{array}{l}\text { Collected under- } \\
\text { wear }\end{array}$ & $51.4(18)$ & $40.0(14)$ & $8.6(3)$ \\
\hline $\begin{array}{l}\text { Combed the pubic } \\
\text { area }\end{array}$ & $60.0(21)$ & $34.3(12)$ & $5.7(2)$ \\
\hline $\begin{array}{l}\text { Removed pubic } \\
\text { hair for reference }\end{array}$ & $48.6(17)$ & $42.9(15)$ & $8.6(3)$ \\
\hline Swabbed vulva & $97.1(34)$ & $3.0(1)$ & $0(0)$ \\
\hline Swabbed vagina & $82.9(29)$ & $17.1(6)$ & $0(0)$ \\
\hline $\begin{array}{l}\text { Swabbed cervical } \\
\text { os }\end{array}$ & $65.7(23)$ & $31.4(11)$ & $2.9(1)$ \\
\hline Swabbed anus & $62.9(22)$ & $34.3(12)$ & $2.9(1)$ \\
\hline Swabbed rectum & $48.6(17)$ & $34.3(12)$ & $17.1(6)$ \\
\hline $\begin{array}{l}\text { Allowed sufficient } \\
\text { time for samples to } \\
\text { dry before sealing }\end{array}$ & $54.3(19)$ & $20.0(7)$ & 25.7 (9) \\
\hline $\begin{array}{l}\text { Sealed samples } \\
\text { personally before } \\
\text { placing in kit }\end{array}$ & $82.9(29)$ & $14.3(5)$ & $2.9(1)$ \\
\hline
\end{tabular}

*Indicates that the option was not available for that particular question.

\section{Collection of forensic evidence}

The sexual assault evidence collection kit (SAECK) is an enabling tool with a checklist of all the evidence that must be collected for forensic purposes. Data obtained in this study revealed that $31.4 \%(n=11)$ of the participants had no knowledge of the SAECK prior to starting their community service, while $68.6 \%$ $(n=24)$ had already been familiar with the SAECK (Table 5$)$. The kit requires that sufficient time is allowed for samples to dry after collection in order to prevent decomposition. Only $54.3 \%(n=19)$ of participants who indicated that they had examined patients who had reported rape or sexual assault always ensured that the samples collected were dry (Yes, always), while $20.0 \%(n=7)$ indicated that they sometimes did (Yes, sometimes) and $25.7 \%$ $(n=9)$ never did (Table 4). Samples should be sealed personally by the examining doctor to preserve the chain of evidence. Among the participants, $82.9 \%(n=29)$ reported sealing the samples personally (Table 4).

\section{Prevention of sexually transmitted infections}

Prescribing treatment for sexually transmitted diseases (STDs) and anti-retroviral (ARV) therapy are deemed necessary for patients reporting being raped, because the lifestyle and HIV status of alleged perpetrators are not known. It is important to note that $91.4 \%(n=32)$ of the participants in this study who indicated that they had examined patients who had been raped 
Table 5: Treatment administered $(n=35)$

\begin{tabular}{lccc}
\hline Factor & $\begin{array}{c}\text { Yes, always } \\
\%(n)\end{array}$ & $\begin{array}{c}\text { Yes, sometimes } \\
\%(n)\end{array}$ & $\begin{array}{c}\text { No } \\
\%(n)\end{array}$ \\
\hline $\begin{array}{l}\text { Prescribed ARVs and } \\
\text { treatment for STDs }\end{array}$ & $91.4(32)$ & $8.6(3)$ & $0(0)$ \\
\hline $\begin{array}{l}\text { Provided a follow-up } \\
\text { date for the patient } \\
\text { to report to the } \\
\text { medical facility }\end{array}$ & $62.9(22)$ & $22.9(8)$ & $14.3(5)$ \\
$\begin{array}{l}\text { Discussed psychoso- } \\
\text { cial follow-up with } \\
\text { the patient }\end{array}$ & $48.6(17)$ & $31.4(11)$ & $20(7)$ \\
\hline
\end{tabular}

Table 6: Undergraduate training for management of patient who reported being raped or sexually assaulted $(n=35)$

\begin{tabular}{lcc}
\hline Factor & Yes \% (n) & No \% (n) \\
\hline Undergraduate training pertaining to rape cases & $80(28)$ & $20(7)$ \\
$\begin{array}{l}\text { Undergraduate hands-on exposure managing a } \\
\text { rape or sexual assault case }\end{array}$ & $11.4(4)$ & $88.6(31)$ \\
$\begin{array}{l}\text { Undergraduate training in completion of J88 } \\
22.9(8)\end{array}$ & $77.1(27)$ \\
\hline
\end{tabular}

or sexually assaulted initiated treatment for STDs and ARV therapy. However, doing so does not appear to be considered essential by all participants, as $8.6 \%(n=3)$ only occasionally initiated treatment (Table 5).

Patients who visited a medical facility after allegedly being raped or sexually assaulted should be informed about appropriate follow-up visits. The aims of the follow-up visits are to collect test results but also to ensure that the medication has been taken as prescribed. Psychosocial follow-up visits should be discussed with patients. As seen in Table 5, 62.9\% $(n=22)$ of the participants always booked patients for a follow-up visit to the medical facility, while only $48.6 \%(n=16)$ of the participants discussed psychosocial follow-up visits with patients.

\section{Undergraduate training for management of rape or sexual assault}

A survey on whether participants in this study had undergone any form of undergraduate training on managing patients who had been raped or sexually assaulted showed that the majority $(80 \%$, $n=28$ ) of the participants had undergone some undergraduate training on managing rape or sexual assault cases. On the other hand, only $11.4 \%(n=4)$ reported having hands-on experience with managing a patient who reported being raped during their undergraduate medical training (Table 6).

\section{Discussion}

In all societies and all facets of life, sexual assault and rape are atrocious crimes, constituting a huge human rights violation and a major health issue for women. ${ }^{7}$ Although most countries now have laws that criminalise sexual assault and rape, obtaining justice for the majority of victims has been largely unsuccessful, as the low conviction rates of alleged offenders demonstrate. ${ }^{8}$ In a study aimed at investigating the barriers to effective use of medico-legal findings in cases of sexual assault, Du Mont and White reported that a lack of competence among law enforcement, forensic scientists, legal and medical professionals who deal with sexual assault and rape cases often negatively impacts on the integrity of medico-legal findings. ${ }^{9}$
With sexual assault and rape being endemic in South Africa, ${ }^{10}$ South African courts rely heavily on medico-legal evidence to support victims' accounts of assault. Hence, it is important that healthcare providers are competent in collecting evidence and documenting proper medico-legal findings as relating to rape and sexual assault.

According to the Health Professions Act (Act No 56 of 1974 [Government Notice. No R.688 as amended by G.N. R.498 of May 2000 and G.N. R.69 of 22 January 2002]), every South African medical graduate is compelled to do one year of community service after completing his/her medical internship training. During this time, they provide and improve healthcare delivery in their host communities and their duties include the delivery of primary health care, which includes clinical forensic medicine. One major component of clinical forensic medicine is the assessment/examination, documentation and treatment of patients who report having been sexually assaulted or raped. These examinations are also known as medico-legal examinations and they entail a very detailed history taking with regard to the incident, and a thorough general examination coupled with the collection of forensic samples.

Training of undergraduate students in clinical forensic medicine is a prerequisite of the Subcommittee for Undergraduate Education and Training of the Medical and Dental Professions Board. Over the years, the undergraduate forensic medicine curriculum has been progressively whittled down through repeated amendments to the syllabus. This has resulted in many community-service doctors being incapable of diligently handling medico-legal cases, and it has led to an increase in the number of acquittals of people accused of rape or sexual assault, resulting in an injustice being done to the victims.

Meticulous history-taking is an integral part of the forensic medical examination of adolescent and adult victims of sexual assault and rape. Comprehensive history-taking enables precise documentation and guides the examiner during the physical examination and the collection of trace-evidence. ${ }^{11}$ History should be taken in a calm, sensitive and non-judgemental manner. ${ }^{12}$ The scope of the history should include the patient's biographical data, date and time of the alleged attack, circumstances of the assault, activities of the victim after the incident, details of any symptoms occurring after the assault, and the sexual/reproductive health history of adolescent and adult patients. ${ }^{12}$ Even more important are points of forensic medical interest that support subsequent findings, namely the details of the alleged rape or sexual assault, and the gynaecological and sexual history of the patient. ${ }^{11}$

This study found that most community-service doctors who participated in the study took detailed histories of the alleged rapes or sexual assaults, as well as gynaecological and sexual histories of patients. It was, however, found that some participants lacked knowledge on the basic principles of clinical forensic examination. Evidence of this lack include their failure to request the patient's consent prior to the examination and failing to ensure that a chaperone is present during the examination (see Table 2). Consent for the examination must be obtained from the patient, or, if the patient is a minor, an accompanying adult family member. ${ }^{12}$ However, obtaining informed consent should not be perceived as a one-off act. Instead, information should be provided at each stage of an examination and verbal consent obtained from the patient for each stage. 
The study also highlighted that not all the participants had sufficient knowledge of the J88 form that they were required to complete (Table 2). The form is used to record the demographic details of the patient, the medical and gynaecological history, and history with regard to the alleged incident. The form also has a section for examination findings and sketches that can be used to demonstrate possible or observed injuries. Poor knowledge of the J88 form may lead to inadequate documentation of both the history and the examination findings. ${ }^{13}$ It was also found that a substantial number (31.4\%) of the participants had no prior knowledge of the SAECK (see Table 4). Although the SAECK is accompanied by extensive user guidelines, it remains a daunting experience to use for the first time. The aim of this kit is to collect forensic evidence, including DNA samples, from the patient. Poor knowledge and improper use of the SAECK negatively affect the quality of the forensic samples collected. ${ }^{14}$

Whilst this study shows that the majority $(80 \%, n=28)$ of the participants had undergone some undergraduate training on the management of rape and sexual assault cases, only $11.4 \%$ $(n=4)$ reported having been involved in the treatment of the victims during their undergraduate medical training (see Table 6). This highlights the need to amend the curriculum for clinical forensic medicine in the $\mathrm{MBChB}$ programme in order to address the shortcomings of the clinical forensic medicine curriculum and to improve the knowledge and skills of medical graduates regarding their medico-legal obligations.

Finally, it should be noted that while most participants responded to most of the questions, the major limitation of this study was the small size of the sample.

\section{Conclusion}

The inept handling, collecting and processing of medico-legal evidence by healthcare providers in cases of rape or sexual assault have been attributed to a lack of rigorous training, and poor performance standards. ${ }^{7}$ Although most of the participants in this study had, during their undergraduate medical training, undergone some form of training on the principles of managing patients reporting rape or sexual assault, only a few of them had hands-on experience before graduating. This study revealed an important gap in medical education and the practice of clinical forensic medicine among community-service doctors. It would be beneficial to revise the clinical forensic medicine curriculum to address the shortcomings in the current $\mathrm{MBChB}$ programme.

\section{ORCID}

AO Adefuye (iD http://orcid.org/0000-0003-2380-1487

\section{References}

1. Naidoo K. Rape in South Africa-a call to action. S Afr Med J. 2013;103(4):210-1. https://doi.org/10.7196/SAMJ.6802

2. Criminal law (sexual offences and related matters) amendment act no. 32 of 2007. Cape Town: Juta \& Co; 2007.

3. Meel BL. An unusual male rape: A case report. South African Family Practice 2009:51(5)

4. South African police service (SAPS). Crime statistics 2015/2016. Pretoria: SAPS Corporate Communications.

5. Vetten L. Rape and other forms of sexual violence in South Africa. Institute for Security Studies, Policy Brief 2014;72:1-7.

6. Jewkes R, Levin J, Mbananga N, et al. Rape of girls in South Africa. The Lancet 2002;359(9303):319-20. https://doi.org/10.1016/S01406736(02)07530-X

7. Du Mont J, White D. Seeking a better world for women and girls. BMJ (Clinical research ed). 2011;343:d5712. doi:10.1136/bmj.d5712.

8. Johnson H, Ollus N, Nevala S. Violence against women: An international perspective. New York: Springer Science \& Business Media. 2007.

9. Du Mont J, White D. Barriers to the effective use of medico-legal findings in sexual assault cases worldwide. Qual Health Res. 2013; Doi:10.1049732313502396.

10. Hirschauer S. Rape and the state-sexual violence and its political narrative and othering in 21 st century South Africa. Africa Insight 2014;44(1):84-102.

11. Ingemann-Hansen $\mathrm{O}$, Charles AV. Forensic medical examination of adolescent and adult victims of sexual violence. Best Practice \& Research Clinical Obstetrics \& Gynaecology 2013;27(1):91-102 https://doi.org/10.1016/j.bpobgyn.2012.08.014

12. Department of Health Republic of South Africa. National management guidelines for sexual assault.2003. Available from: https://www. cecinfo.org/custom-content/uploads/2012/12/SouthAfrica-SexualAssault-Guidelines-2003.pdf

13. Rowe $\mathrm{K}$, Botha $\mathrm{H}$, Mahomed $\mathrm{H}$, et al. Justice through the J88: The doctor's role in the criminal justice system. S Afr Med J. 2013;103(7):437-8. doi:10.7196/SAMJ.7084.

14. Budowle B, Schutzer SE, Burans JP, et al. Quality sample collection, handling, and preservation for an effective microbial forensics program. Appl Environ Microbiol. 2006;72(10):6431-8. doi:10.1128/ AEM.01165-06. 